\title{
Взаимосвязь эго-компетентности личности и способности к пониманию другого человека в юношеском возрасте
}

\section{Татьяна Б. Юшачкова}

Магнитогорский государственный технический университет им. Г. И. Носова, г. Магнитогорск, Российская Федерация

E-mail: tat_yushachkova@mail.ru

\begin{abstract}
Аннотация
Ввеление. Представлены результаты исследования взаимосвязи межАу компетентностью ^ичности в собственном Я (эго-компетентностью) И способностью к пониманию Аругого человека в юношеском возрасте. Новизна исследования в комплексном изучении связи эго-компетентности личности с такими параметрами способности, как: коммуникативно-личностный потенциал субъекта познания, понимание состояния Аругого человека по его невербальному поведению, точность прогнозирования развития ситуации межличностного взаимодействия, самооценка способности к пониманию людей. Рассмотрен уровень развития юношей и Аевушек с высокими и низкими показателями эго-компетентности Аичности как субъектов межличностного познания.

Методы. Описывается блок Аиагностических средств, используемых в исслеАовании, среди них: методики, разработанные В.Н. Куницыной - тест «Притчи», опросник КОСКОМ (Коммуникативная и социальная компетентность), метоАика СТА^ь (Стабильность, толерантность и альтруизм в межличностных отношениях, и Аругие свойства мичности), опросник СУМО (Саморегуляция и успешность межличностного общения), тест «Самооценка», а также тест «Экспрессия» (моАифицированный вариант субтеста «группы экспрессии» методики исслеАования социального интемлекта Аж. Ги^фрорАа и М. Салмивена), 16-фракторный опросник Р. Кеттел^а. Выборку исследования составили студенты Магнитогорского государственного технического университета в количестве 125 человек.
\end{abstract}

Результаты. Установлено наличие в юношеском возрасте положительной связи межАу показателями эго-компетентности личности, коммуникативно-Аичностного потенциала и самооценки понимания Аюдей. Связи эго-компетентности с пониманием состояния Аругого человека по его невербальному поведению и точностью прогнозирования развития ситуации межличностного взаимодействия не явАяются статистически Аостоверными.

ОбсужАение результатов. Анализ полученных Аанных свиАетельствует о неоАнозначной связи в юношеском возрасте эго-компетентности Аичности с отАельными 
психология личности

составляющими способности к пониманию Аругих АюАей. Компетентность в собственном Я сочетается с высокой оценкой своей способности к пониманию Аругих ^юАей и не всегАа согласуется с Успешностью в понимании состояния Аругого человека по его невербальным реакциям, точностью прогнозирования развития ситуации межличностного взаимодействия.

\section{КАючевые слова}

юношеский возраст, общение, субъект познания, межличностное понимание, точность понимания, эго-компетентность мичности, коммуникативно-личностный потенциал, понимание невербального поведения, понимание развития ситуации

\section{Основные положения}

- компетентность в собственном Я в юношеском возрасте напрямую связана С высокой самооценкой понимания Аругих ^юАей и не имеет оАнозначных связей с пониманием невербального поведения и точностью прогнозирования развития ситуации межличностного взаимодействия;

- эго-компетентных юношей и девушек отличает высокий уровень развития коммуникативно-личностного потенциала;

- во взаимосвязи отАельных СоставАяющих способности к пониманию Аругих ^ЮАей со свойствами мичности можно вылелить как общие, так и специфические, обусловленные уровнем эго-компетентности мичности, связи.

\section{Для цитирования}

Юшачкова Т.Б. Взаимосвязь эго-компетентности личности и способности к пониманию другого человека в юношеском возрасте // Российский психологический журнал. 2018. T. 15, № 2. C. 83-107. DOI: 10.21702/rpj.2018.2.4

Материалы статьи получены 08.10.2017

UDC 159.99

DOI: 10.21702/rpj.2018.2.4

\section{Interrelation Between Personal Ego-Competence and the Ability to Understand Another Person in Adolescence}

\section{Tat'yana B. Yushachkova}

Nosov Magnitogorsk State Technical University, Magnitogorsk, Russian Federation E-mail: tat yushachkova@mail.ru

\footnotetext{
Abstract

Introduction. The paper presents the results of the study of interrelation between personal ego-competence (synonymous to self-competence) and the ability to 


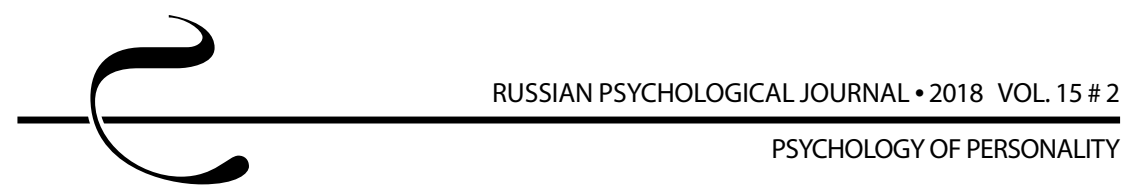

understand another person in adolescence. The novelty of the research lies in its complex approach to studying the association of personal ego-competence with the following parameters of communicative abilities: personal communicative potential of the subject of cognition, understanding of another person's state by his/her nonverbal behavior, accuracy of predicting the development of an interpersonal communication situation, and self-rating of the ability to understand others. The paper investigates the levels of communicative development of young boys and girls with high and low indices of personal ego-competence, where the study participants are considered to be the subjects of interpersonal cognition.

Methods. The study used the following diagnostic tools developed by V. N. Kunitsyna: (a) the Parables test; (b) the Communicative and Social Competence survey (COSCOM); (c) the technique for revealing Stability, Tolerance, and Altruism in interpersonal relations and other personality traits (STAL); (d) the survey for identifying Self-regulation and Success of Interpersonal Communication (SSIC); (e) and the Self-Appraisal test. The study also employed the Expression test, a modified version of the Expression Grouping subtest in Six Factor Test of Social Intelligence by J. Guilford and M. Sullivan, and the Sixteen Personality Factor Questionnaire (16PF). Students from Magnitogorsk State Technical University $(n=125)$ formed the study sample.

Results. The results indicate that the parameters of personal ego-competence in adolescence have positive associations with the personal communicative potential and self-rating of the ability to understand others. No statistically significant associations were found between ego-competence and either understanding of another person's state by his/her nonverbal behavior, or accuracy of predicting the development of an interpersonal communication situation.

Discussion. The findings of the study suggest that adolescents' ego-competence has ambiguous associations with particular components of the ability to understand others. Ego-competence is associated with respondents' high estimates of their ability to understand others, but is not always accompanied by success in understanding of another person's state by his/her nonverbal behavior and the accuracy of predicting the development of an interpersonal communication situation.

\section{Keywords}

adolescence, communication, subject of cognition, interpersonal understanding, accuracy of understanding, personal ego-competence, personal communicative potential, understanding of nonverbal behavior, understanding the development of a situation

\section{Highlights}

- Adolescents' ego-competence is directly associated with a high level of self-rating of understanding others, but has no clear association with understanding non-verbal 
behaviour and with the accuracy of predicting the development of an interpersonal communication situation.

- Ego-competent young boys and girls are characterized by a high level of personal communicative potential.

- Personality traits have both general and specific associations with particular components of the ability to understand other people, which depend on the level of personal ego-competence.

\section{For citation}

Yushachkova T. B. Interrelation Between Personal Ego-Competence and the Ability to Understand Another Person in Adolescence. Rossiiskii psikhologicheskii zhurnal - Russian Psychological Journal, 2018, V. 15, no. 2., pp. 83-107 (in Russian). DOI: 10.21702/rpj.2018.2.4

Original manuscript received 08.10.2017

\section{Введение}

В психологии накоплено большое количество эмпирического материала о познании людьми друг друга, о личностных особенностях субъекта познания, определяющих понимание им другого человека: его состояний, свойств личности и мотивов поступков [1, 2, 3, 4, 5, 6, 7, 8, 9].

Имеющиеся на сегодняшний день данные позволяют с уверенностью говорить о большой роли в процессе понимания другого человека компетентности познающего в собственном Я, знания себя, т. е. наличия эго-компетентности или Я-компетентности (данные понятия употребляются нами в качестве синонимов).

Вместе с тем представляется актуальным изучение данного фактора в контексте различных составляющих способности к пониманию других людей.

Философский уровень анализа проблемы свидетельствует о наличии разных подходов к вопросу о взаимосвязи эго-компетентности личности и понимания других людей.

С позиции экзистенциальной философии полное и абсолютное знание и понимание людьми друг друга невозможно. В процессе познания люди превращают друг друга в «объект», «предмет», в «Оно», в «набор качеств и свойств», схематизируют и умерщвляют свободу друг друга (М. Бубер, Ж.-П. Сартр, К. Ясперс). При этом другой человек нужен - он выполняет важную функцию в процессе самопознания и самопонимания. Философы отмечают, что «в качестве единичного я для себя не раскрыт, не действителен» (К. Ясперс), «я становлюсь собой лишь через свое отношение к Ты» (М. Бубер), «взгляд Другого с самого начала является посредником, который отсылает меня ко мне же» (Ж.-П. Сартр) [10, 11, 12]. 
Представители философии марксизма также придавали большое значение социальной обусловленности процесса познания людьми самих себя. К. Маркс писал: «в некоторых отношениях человек напоминает товар. Так как он родится без зеркала в руках и не фихтеанским философом: “Я есмь я", то человек сначала смотрится, как в зеркало, в другого человека. Лишь отнесясь к человеку Павлу как к себе подобному, человек Петр начинает относиться к самому себе как к человеку» [13, с. 62]. Помимо этого они допускали возможность познания и понимания людьми друг друга.

Обращаясь к истории изучения проблемы межличностного понимания в рамках психологии, следует отметить, что еще в 1937 г. Г. Олпортом среди свойств, необходимых проницательному человеку, было выделено «глубокое понимание себя». Помимо этого, в перечень отличающих его особенностей входили: опыт, под которым понималась зрелость личности, предполагающая не только достижение определенного возраста, но и наличие опыта взаимодействия с другими людьми в различных ситуациях; сходство между собой и познаваемым человеком; высокий уровень интеллекта; сложность; отстраненность, способность посмотреть на людей и события со стороны; эстетические склонности и социальный интеллект [14].

В последующих эмпирических исследованиях было установлено влияние на понимание другого человека уровня когнитивной сложности личности, развития самосознания и представления о себе, а также самооценки $[15,16,17]$.

В основе отечественного подхода к проблеме личностных детерминант понимания людьми друг друга лежит положение, согласно которому отражение человеком действительности опосредовано особенностями, которые характеризуют его как личность, как субъекта труда, познания и общения [18, 19].

Изучая восприятие и понимание людьми друг друга, А.А. Бодалев писал: «выступая в качестве объекта познания и действия, человек отражается в сознании людей и определяет их поведение, лишь "преломляясь" через их внутренний мир, сложившийся строй мыслей и отношений» [20, с. 56].

Степень развития субъекта познания как личности влияет на содержание формирующегося у него понятия о личности воспринимаемого человека.

Восприятие другого человека напрямую связано с самовосприятием.

Г.М. Андреева в этой связи указывала на то, что «с одной стороны, богатство представлений о самом себе определяет и богатство представлений о другом человеке, с другой стороны, чем более полно раскрывается другой человек (в большем количестве и более глубоких характеристиках), тем более полным становится и представление о самом себе» [21, с. 119].

По мнению Л.А. Петровской, можно проследить симметрию основных источников восприятия себя и другого человека [22, с. 393-396]: 
- «восприятие себя через соотнесение (идентификацию, различение) себя с другими» - «восприятие другого через соотнесение (идентификацию, различение) другого с собой»;

- «восприятие себя через восприятие себя другими» - «восприятие другого через то, как его воспринимают другие»;

- «восприятие себя через результаты собственной деятельности» - «восприятие другого через восприятие результатов его деятельности»;

- «восприятие себя через наблюдение собственных внутренних состояний» - «непосредственное восприятие внешнего облика другого»;

- «непосредственное восприятие собственного внешнего облика» - «восприятие другого через экспликацию им своих внутренних состояний».

В формировании человека как субъекта межличностного познания большая роль принадлежит общению, неотъемлемой стороной которого является восприятие и понимание партнерами друг друга. С увеличением опыта общения понятия о других людях становятся более содержательными и точными [23, 24, 25, 26, 27].

Ряд ученых отмечают прямую связь между компетентностью личности в общении и эго-компетентностью. Так, если рассматривать в качестве структурных компонентов общения его участников, ситуацию и задачу, то, по мнению Л. А. Петровской, основными образующими компетентности в общении могут выступать: компетентность человека в самом себе (Я-компетентность), т. е. его адекватная ориентация в собственном психологическом потенциале, а также в потенциале партнера, компетентность в ситуации и задаче. Я-компетентность при этом является первичной и базовой образующей компетентности в общении, именно она определяет качество других ее составляющих, а также результата [22].

По данным исследований, точному пониманию личностных особенностей другого человека способствуют адекватное отражение собственных личностных свойств и принятие себя. Излишняя самоуверенность либо, напротив, недооценка своих возможностей приводит к неадекватному пониманию личностных особенностей другого человека [28, 29, 30, 31].

В то же время установлено, что неуверенность в себе, тревожность личности нередко сочетаются с успешностью распознавания эмоциональных состояний по выражению лица, способствуют адекватности оценки состояния другого человека по его голосу $[32,33]$. Для людей, отличающихся слабым проникновением в собственную личность, недостаточным знанием своего Я, характерно приписывание другому человеку особенностей собственных психических процессов и свойств. Элементы образа Я, которые человек хочет вытеснить, забыть, также становятся источниками непонимания людей [20]. 


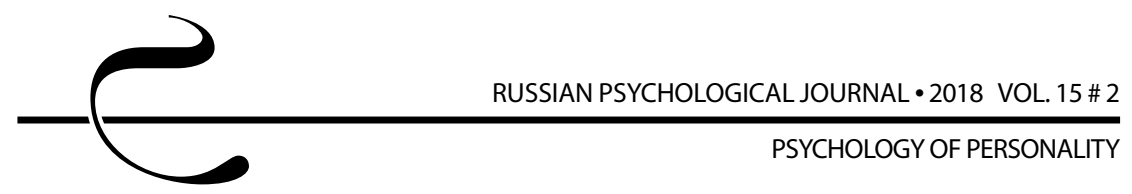

В целях более глубокого изучения взаимосвязи между эго-компетентностью личности и способностью к пониманию других людей в юношеском возрасте нами было проведено исследование, в задачу которого входил анализ связи эго-компетентности с четырьмя параметрами, рассматриваемыми нами в качестве составляющих способности к пониманию: коммуникативноличностным потенциалом субъекта познания, точностью прогнозирования развития ситуации межличностного взаимодействия, пониманием состояния другого человека по его невербальному поведению, самооценкой способности к пониманию других людей.

Следует отметить, что коммуникативно-личностный потенциал занимает особое место в ряду изучаемых параметров: он является коммуникативным ядром социального интеллекта личности и отражает уровень развития у субъекта способности к пониманию других людей. Остальные напрямую свидетельствуют об уровне развития у субъекта данной способности.

\section{Методы}

В работе был использован широкий набор диагностических средств, направленный на изучение эго-компетентности и способности к пониманию людей, их взаимосвязи в юношеском возрасте. В частности, показатели способности к пониманию состояния человека по его невербальному поведению были получены с помощью теста «Экспрессия», являющегося модифицированным вариантом субтеста «группы экспрессии» методики исследования социального интеллекта Дж. Гилфорда и М. Салливена. Уровень коммуникативно-личностного потенциала диагностировался по методике СУМО (Саморегуляция и успешность межличностного общения) (автор В.Н. Куницына). Изучение способности к точному прогнозированию развития ситуации межличностного взаимодействия проводилось с помощью полупроективного теста «Притчи», состоящего из неоконченных историй-притч (автор В.Н. Куницына). В процессе диагностики испытуемым зачитывалось начало притчи, а затем предлагались варианты ее окончания, из которых они должны были выбрать, по их мнению, наиболее правдоподобный. Оценка способности к пониманию людей осуществлялась по результатам шкалы самооценочного опросника КОСКОМ (Коммуникативная и социальная компетентность) (автор В.Н. Куницына). Об эго-компетентности личности свидетельствовали показатели по шкале «эго-компетентность» методики КОСКОМ, направленной на измерение знания себя. Помимо этого, с помощью методик СУМО и КОСКОМ, методики СТАЛЬ (Стабильность, толерантность и альтруизм в межличностных отношениях, и другие свойства личности) (автор В.Н. Куницына), а также 16-факторного опросника Р. Кеттелла и теста «Самооценка» (автор В.Н. Куницына) была получена дополнительная информация об уровне 
развития личностных свойств и социально-психологических навыков испытуемых, необходимая для разностороннего изучения проблемы.

Максимальное значение выраженности изучаемых параметров по всем используемым методикам соответствовало 12-ти баллам.

Математико-статистическая обработка данных была реализована с помощью программного пакета SPSS 17.0. и заключалась в расчете достоверности различия средних величин (U-критерий Манна - Уитни), проведении корреляционного анализа Пирсона и регрессионного анализа.

Выборка включала юношей и девушек - студентов Магнитогорского государственного технического университета в возрасте от 18 до 20 лет в количестве 125 человек.

\section{Результаты}

По данным исследования среднегрупповой показатель эго-компетентности субъектов межличностного познания юношеского возраста составил 6,32 баллов из 12-ти максимально возможных по тесту, что свидетельствует о среднем уровне знания себя, своих индивидуальных особенностей, достоинств и недостатков.

Анализ распределения признака показал, что большинство опрошенных респондентов (56\%) обладают средним уровнем эго-компетентности, $14 \%$ высоко оценили знание себя и $30 \%$ - испытывают значительные трудности в самопознании.

В таблице 1 представлены результаты исследования корреляции между показателями эго-компетентности и отдельными параметрами личности.

Таблица 1. Взаимосвязь эго-компетентности с отАельными параметрами ^ичности

Table 1. Associations between ego-competence and particular personality parameters

\begin{tabular}{|c|c|c|c|}
\hline $\begin{array}{c}\text { Параметры } \\
\text { Parameters }\end{array}$ & $\begin{array}{c}\text { Эго-компе- } \\
\text { тентность } \\
\text { Ego-competence }\end{array}$ & $\begin{array}{c}\text { Параметры } \\
\text { Parameters }\end{array}$ & $\begin{array}{c}\text { Эго-компе- } \\
\text { тентность } \\
\text { Ego-competence }\end{array}$ \\
\hline $\begin{array}{l}\text { Оперативная } \\
\text { социальная } \\
\text { компетентность } \\
\text { Operational social } \\
\text { competence }\end{array}$ & $0,45^{* * *}$ & $\begin{array}{l}\text { Боязнь } \\
\text { отвержения } \\
\text { Fear of rejection }\end{array}$ & $-0,30^{* * *}$ \\
\hline $\begin{array}{l}\text { Сноровка } \\
\text { Proficiency }\end{array}$ & $0,44^{* * *}$ & $\begin{array}{l}\text { Эмоциональная } \\
\text { незрелость } \\
\text { Emotional } \\
\text { immaturity }\end{array}$ & $-0,29 * *$ \\
\hline
\end{tabular}




\begin{tabular}{|c|c|c|c|}
\hline $\begin{array}{l}\text { Параметры } \\
\text { Parameters }\end{array}$ & $\begin{array}{c}\text { Эго-компе- } \\
\text { тентность } \\
\text { Ego-competence }\end{array}$ & $\begin{array}{l}\text { Параметры } \\
\text { Parameters }\end{array}$ & $\begin{array}{c}\text { Эго-компе- } \\
\text { тентность } \\
\text { Ego-competence }\end{array}$ \\
\hline $\begin{array}{l}\text { УАовлетворенность } \\
\text { общением в близ- } \\
\text { ком кругу } \\
\text { Satisfaction with } \\
\text { communication in } \\
\text { the inner circle }\end{array}$ & $0,44^{* * *}$ & $\begin{array}{l}\text { Adpфилиация } \\
\text { Affiliation }\end{array}$ & $0,28 * *$ \\
\hline $\begin{array}{l}\text { Коммуникативная } \\
\text { компетентность } \\
\text { Communicative } \\
\text { competence }\end{array}$ & $0,39 * * *$ & $\begin{array}{l}\text { Ханжество } \\
\text { Hуросrisy }\end{array}$ & $-0,28^{* *}$ \\
\hline $\begin{array}{l}\text { Зависимость } \\
\text { Dependence }\end{array}$ & $-0,38^{* * *}$ & $\begin{array}{l}\text { Самодостаточ- } \\
\text { ность } \\
\text { Self-sufficiency }\end{array}$ & $0,27^{* *}$ \\
\hline $\begin{array}{l}\text { Социально- } \\
\text { психологическая } \\
\text { компетентность } \\
\text { Social and psycho- } \\
\text { logical competence }\end{array}$ & $0,38^{* * *}$ & $\begin{array}{l}\text { Эмоциональная } \\
\text { стабильность } \\
\text { Emotional } \\
\text { stability }\end{array}$ & $0,27^{* *}$ \\
\hline $\begin{array}{l}\text { Уверенность } \\
\text { Confidence }\end{array}$ & $0,38^{* * *}$ & $\begin{array}{l}\text { Тревожность } \\
\text { Anxiety }\end{array}$ & $-0,27^{* *}$ \\
\hline $\begin{array}{l}\text { Навыки общения } \\
\text { Communication skills }\end{array}$ & $0,37^{* * *}$ & $\begin{array}{l}\text { Высокая само- } \\
\text { оценка, само- } \\
\text { уверенность } \\
\text { High self-esteem, } \\
\text { self-assurance }\end{array}$ & $0,23^{*}$ \\
\hline $\begin{array}{l}\text { Эмоциональная } \\
\text { устойчивость } \\
\text { Emotional resilience }\end{array}$ & $0,33^{* * *}$ & $\begin{array}{l}\text { Смелость } \\
\text { Courage }\end{array}$ & $0,21^{*}$ \\
\hline $\begin{array}{l}\text { Оптимизм } \\
\text { Optimism }\end{array}$ & $0,32^{* * *}$ & $\begin{array}{l}\text { Сенситивность } \\
\text { Sensitivity }\end{array}$ & $-0,20^{*}$ \\
\hline $\begin{array}{l}\text { Предрассудки } \\
\text { Prejudices }\end{array}$ & $-0,32^{* * *}$ & $\begin{array}{l}\text { Благоже- } \\
\wedge \text { ательность } \\
\text { Benevolence }\end{array}$ & $0,19 *$ \\
\hline $\begin{array}{l}\text { Вербальная } \\
\text { компетентность } \\
\text { Verbal competence }\end{array}$ & $0,31^{* * *}$ & $\begin{array}{l}\text { Толерантность } \\
\text { Tolerance }\end{array}$ & $0,18^{*}$ \\
\hline
\end{tabular}

Примечание: ${ }^{* *} p<0,001 ;{ }^{* *} p<0,01 ;{ }^{*} p<0,05$.

Note: ${ }^{* *} p<0,001 ;{ }^{* *} p<0,01 ;{ }^{*} p<0,05$. 
Согласно полученным данным, эго-компетентность в юношеском возрасте сочетается с эмоциональной зрелостью личности, самодостаточностью, высокой самооценкой, уверенностью в себе, независимостью, оптимистичностью, удовлетворенностью общением в близком кругу, низким уровнем тревожности, сенситивности и при этом благожелательностью по отношению к другим людям, толерантностью, стремлением к близким, доверительным отношениям, не боязнью быть отвергнутыми людьми, отсутствием предрассудков и ханжеских установок, социально-психологической компетентностью, развитыми коммуникативными умениями и навыками, высокой общей социальной ориентированностью и осведомленностью, сноровкой, смелостью.

Обратимся к показателям сформированности испытуемых как субъектов межличностного познания (рисунок 1).

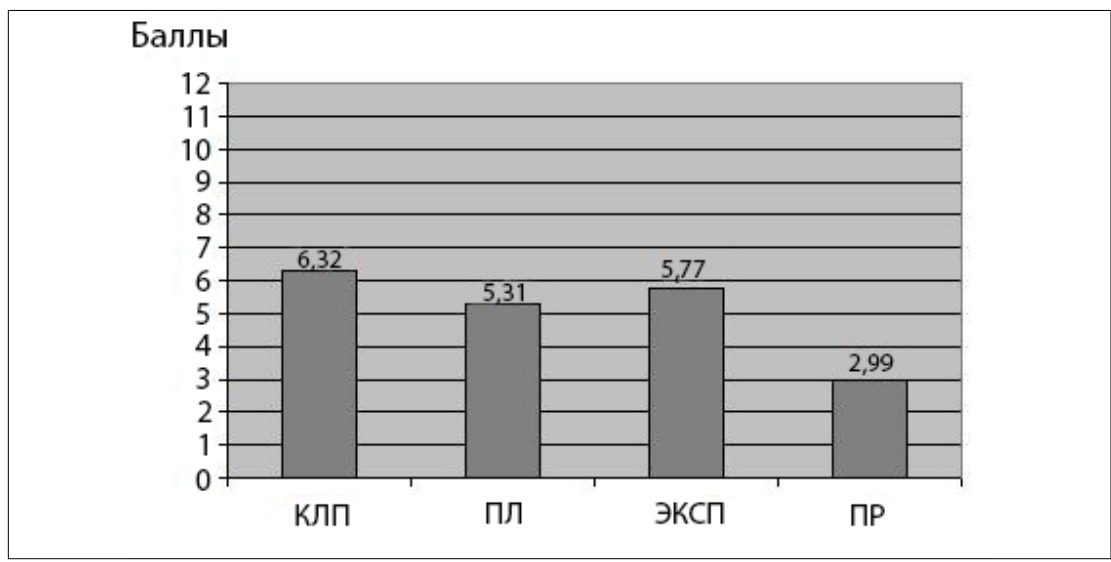

Рисунок 1. Показатели развития отАельных составляющих способности к пониманию Аругих АюАей

Условные обозначения: КЛП - коммуникативно-личностный потенциал; ПЛ - понимание людей; ЭКСП - понимание состояния человека по его невербальному поведению; ПР - точность прогнозирования развития ситуации межличностного взаимодействия.

Figure 1. Indices of particular components of the ability to understand others

Legend: $P C P$ - personal communicative potential; $U O$ - understanding others; EXP - understanding of another person's state by his/her nonverbal behavior; AP - accuracy of predicting the development of an interpersonal communication situation.

Являясь субъектами межличностного познания, юноши и девушки нередко ошибаются в понимании других людей - показатели развития у них отдельных составляющих способности к пониманию людей находятся в диапазоне от низких до средних величин. 
Обладая средним уровнем развития коммуникативно-личностного потенциала, они достаточно низко оценивают свою способность к пониманию людей. Как показывают тестовые задания, значительные затруднения у них вызывает прогнозирование развития ситуации межличностного взаимодействия, предполагающее понимание мотивов поведения ее участников. Более успешны юноши и девушки в понимании невербального поведения; показатели развития данной способности находятся на среднем уровне.

Данные о взаимосвязи эго-компетентности личности с отдельными составляющими способности к пониманию других людей в юношеском возрасте приведены на рисунке 2.

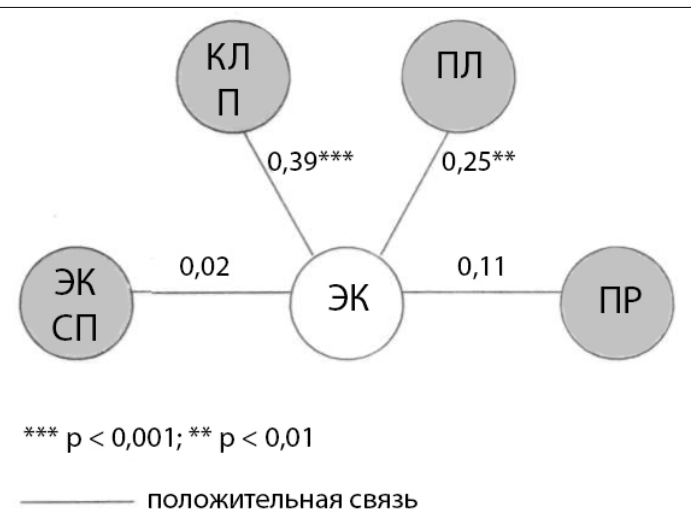

Рисунок 2. Корреляционные связи эго-компетентности с отАельными составляющими способности к пониманию Аругих АюАей

Условные обозначения: ЭК - эго-компетентность личности; КЛП-коммуникативно-личностный потенциал; ПЛ - понимание людей; ЭКСП - понимание состояния человека по его невербальному поведению; ПР - точность прогнозирования развития ситуации межличностного взаимодействия.

Figure 2. Correlations between self-competence and particular components of the ability to understand others

Legend: $E C$ - personal ego-competence; $P C P$ - personal communicative potential; $U O$ - understanding others; EXP - understanding of another person's state by his/her nonverbal behavior; AP - accuracy of predicting the development of an interpersonal communication situation.

Как видно из рисунка 2, эго-компетентность личности положительно коррелирует с коммуникативно-личностным потенциалом $(r=0,39 ; p<0,001)$ и с самооценкой способности к пониманию людей $(r=0,25 ; p<0,01)$. Связи с остальными параметрами понимания не являются статистически значимыми. 
Таким образом, в юношеском возрасте высокий уровень компетентности личности в своем Я, знание себя сочетаются с высоким уровнем развития коммуникативно-личностного потенциала и уверенностью в собственной способности понимания других людей. Точность прогнозирования развития ситуации межличностного взаимодействия и понимание состояния другого человека по его невербальному поведению могут сочетаться с разным уровнем развития эго-компетентности личности.

По результатам регрессионного анализа 15,3\% дисперсии показателя коммуникативно-личностного потенциала и 6,2\% дисперсии показателя самооценки способности к пониманию людей обусловлено влиянием со стороны эго-компетентности личности.

В целях исследования нами были сформированы группы испытуемых с высоким и низким уровнями эго-компетентности личности. В каждую из них вошло по 15 человек.

Подсчет U-критерия Манна - Уитни показал наличие статистически значимых различий между группами по ряду параметров (таблица 2).

Таблица 2. Статистически значимые различия межАу испытуемыми с высоким и низким уровнями эго-компетентности

Table 2. Significant differences between the respondents with high and low levels of ego-competence

\begin{tabular}{|c|c|c|c|}
\hline $\begin{array}{c}\text { Показатели } \\
\text { Indices }\end{array}$ & $\begin{array}{c}\text { Высокий уро- } \\
\text { вень эго-ком- } \\
\text { петентности } \\
\text { (средние) } \\
\text { High level of } \\
\text { ego-compe- } \\
\text { tence (mean } \\
\text { scores) }\end{array}$ & $\begin{array}{l}\text { Низкий уро- } \\
\text { вень эго-ком- } \\
\text { петентности } \\
\text { (средние) } \\
\text { Low level of } \\
\text { ego-compe- } \\
\text { tence (mean } \\
\text { scores) }\end{array}$ & $\begin{array}{c}\text { Значимость } \\
\text { U-критерия } \\
\text { Манна - } \\
\text { Уитни } \\
\text { Mann- } \\
\text { Whitney } \\
\text { U test (p) }\end{array}$ \\
\hline $\begin{array}{l}\text { Эмоциональная } \\
\text { устойчивость } \\
\text { Emotional resilience }\end{array}$ & 6,13 & 3,73 & $p<0,05$ \\
\hline $\begin{array}{l}\text { Эмоциональная } \\
\text { стаби^ьность } \\
\text { Emotional stability }\end{array}$ & 9,2 & 6,53 & $p<0,05$ \\
\hline $\begin{array}{l}\text { Оптимизм } \\
\text { Optimism }\end{array}$ & 10,33 & 8,67 & $p<0,05$ \\
\hline $\begin{array}{l}\text { Уверенность } \\
\text { Confidence }\end{array}$ & 8,07 & 4,8 & $p<0,01$ \\
\hline
\end{tabular}




\begin{tabular}{|c|c|c|c|}
\hline $\begin{array}{c}\text { Показате^и } \\
\text { Indices }\end{array}$ & $\begin{array}{c}\text { Высокий уро- } \\
\text { вень эго-ком- } \\
\text { петентности } \\
\text { (средние) } \\
\text { High level of } \\
\text { ego-compe- } \\
\text { tence (mean } \\
\text { scores) }\end{array}$ & $\begin{array}{l}\text { Низкий уро- } \\
\text { вень эго-ком- } \\
\text { петентности } \\
\text { (средние) } \\
\text { Low level of } \\
\text { ego-compe- } \\
\text { tence (mean } \\
\text { scores) }\end{array}$ & $\begin{array}{c}\text { Значимость } \\
\text { U-критерия } \\
\text { Манна - } \\
\text { Уитни } \\
\text { Mann- } \\
\text { Whitney } \\
\text { U test (p) }\end{array}$ \\
\hline $\begin{array}{l}\text { Зависимость } \\
\text { Dependence }\end{array}$ & 5,87 & 8,4 & $p<0,01$ \\
\hline $\begin{array}{l}\text { Боязнь отвержения } \\
\text { Fear of rejection }\end{array}$ & 6,13 & 7,93 & $p<0,05$ \\
\hline $\begin{array}{l}\text { УАовлетворенность обще- } \\
\text { нием в близком кругу } \\
\text { Satisfaction with communi- } \\
\text { cation in the inner circle }\end{array}$ & 7,93 & 4,13 & $p<0,01$ \\
\hline $\begin{array}{l}\text { Социально- } \\
\text { психологическая } \\
\text { компетентность } \\
\text { Social and psychological } \\
\text { competence }\end{array}$ & 6,6 & 4,2 & $p<0,05$ \\
\hline $\begin{array}{l}\text { Оперативная социальная } \\
\text { компетентность } \\
\text { Operational social } \\
\text { competence }\end{array}$ & 6,93 & 3,27 & $p<0,01$ \\
\hline $\begin{array}{l}\text { Коммуникативная } \\
\text { компетентность } \\
\text { Communicative } \\
\text { competence }\end{array}$ & 8,07 & 4,8 & $p<0,01$ \\
\hline $\begin{array}{l}\text { Вербальная } \\
\text { компетентность } \\
\text { Verbal competence }\end{array}$ & 6,6 & 4,33 & $p<0,05$ \\
\hline $\begin{array}{l}\text { Навыки общения } \\
\text { Communication skills }\end{array}$ & 8,6 & 5,33 & $p<0,01$ \\
\hline $\begin{array}{l}\text { Предрассудки } \\
\text { Prejudices }\end{array}$ & 7,13 & 8,2 & $p<0,05$ \\
\hline $\begin{array}{l}\text { CHоровка } \\
\text { Proficiency }\end{array}$ & 8,73 & 6,13 & $p<0,01$ \\
\hline $\begin{array}{l}\text { Асоциальность повеАения } \\
\text { Asocial behavior }\end{array}$ & 5,4 & 7,4 & $p<0,05$ \\
\hline
\end{tabular}


На основании полученных данных можно утверждать, что испытуемые юношеского возраста с высоким уровнем эго-компетентности склонны к анализу своих поступков, хорошо знают свои достоинства и недостатки, уверены в себе, эмоционально устойчивы, умеют контролировать свои чувства и эмоции, спокойны и жизнерадостны, удовлетворены общением с близкими людьми. Они не ощущают себя людьми, полностью зависимыми от окружающих, обладают хорошо развитыми коммуникативными умениями и навыками, а также общей социальной ориентированностью и осведомленностью, что делает их успешными в социальном взаимодействии; считают себя людьми активными и предприимчивыми.

В отличие от них, люди с низким уровнем эго-компетентности эмоционально нестабильны, импульсивны, не очень хорошо знают особенности своего характера; им не свойственно проводить анализ того, как они поступили в той или иной ситуации. У них много внутренних запретов и комплексов, они не уверены в себе и зависимы от окружающих людей и обстоятельств, боятся быть отвергнутыми, не удовлетворены общением с близкими людьми. Отмечают низкий уровень развития коммуникативных навыков, социальной ориентированности и осведомленности, испытывают трудности в социальном взаимодействии, способны к совершению асоциальных поступков.

Показатели развития отдельных составляющих способности к пониманию других людей, представленные на рисунке 3, свидетельствуют о том, что испытуемые с высоким уровнем эго-компетентности несколько более успешны в межличностном понимании. Вместе с тем их показатели не превышают средних величин.

Эго-некомпетентные испытуемые не очень высоко оценивают свою способность к пониманию людей, хотя, по данным исследования, показатели понимания ими состояния другого человека по его невербальному поведению соответствуют среднему уровню. Особые трудности у испытуемых обеих групп вызывает анализ развития ситуации межличностного взаимодействия.

Как показал подсчет U-критерия Манна - Уитни, эго-компетентные люди на уровне статистической значимости имеют более высокий (выше среднего) уровень развития коммуникативно-личностного потенциала. По остальным параметрам различия не являются значимыми.

В ходе корреляционного анализа у эго-компетентных испытуемых были установлены следующие взаимосвязи между отдельными параметрами понимания и свойствами личности, представленные на рисунке 4.

У эго-компетентных испытуемых высокий уровень коммуникативноличностного потенциала наиболее тесно связан с эго-компетентностью и коммуникативной компетентностью личности. Установленные связи вполне 
закономерны, поскольку данные параметры свидетельствуют о развитии самосознания личности, ее коммуникативной сферы.

Успешность в социальном взаимодействии и общении во многом определяется уровнем развития эмоциональной сферы. Об этом говорят связи коммуникативно-личностного потенциала с показателями, отражающими эмоциональную устойчивость, спокойствие личности, низкий уровень сенситивности, оптимистичность.

Помимо этого, связи с самодостаточностью личности, критичностью по отношению к собственной работоспособности, руководством не устоявшимися нормами морали, а своими установками, способностью к децентрации, - указывают на то, что высокий уровень развития коммуникативно-личностного потенциала сочетается с уверенностью человека в себе, ориентированностью как на свои мнения и убеждения, так и на окружающих. Такая социальная гибкость способствует успешности личности в общении, в достижении поставленных целей.

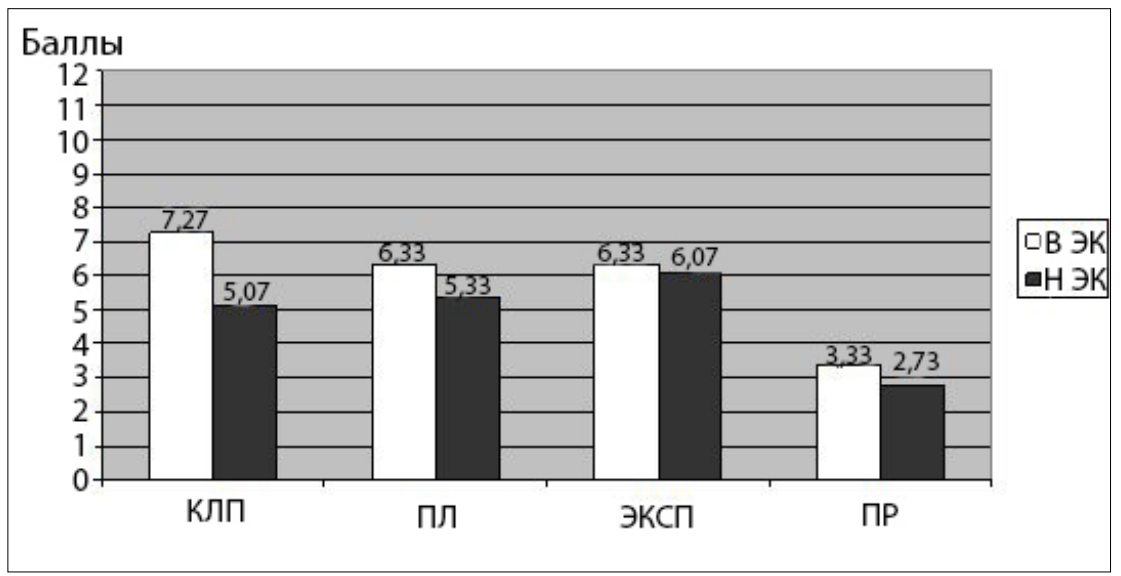

Рисунок 3. Показатели развития отАельных составляющих способности К пониманию Аругих АюАей

Условные обозначения: КЛП - коммуникативно-личностный потенциал; ПЛ - понимание людей; ЭКСП - понимание состояния человека по его невербальному поведению; ПР - точность прогнозирования развития ситуации межличностного взаимодействия; В ЭК - высокий уровень эго-компетентности; Н ЭК - низкий уровень эго-компетентности.

Figure 3. Indices of particular components of the ability to understand others

Legend: $P C P$ - personal communicative potential; $U O$ - understanding others; EXP - understanding of another person's state by his/her nonverbal behavior; $A P$ - accuracy of predicting the development of an interpersonal communication situation; HEC - high level of ego-competence; LEC - low level of ego-competence. 


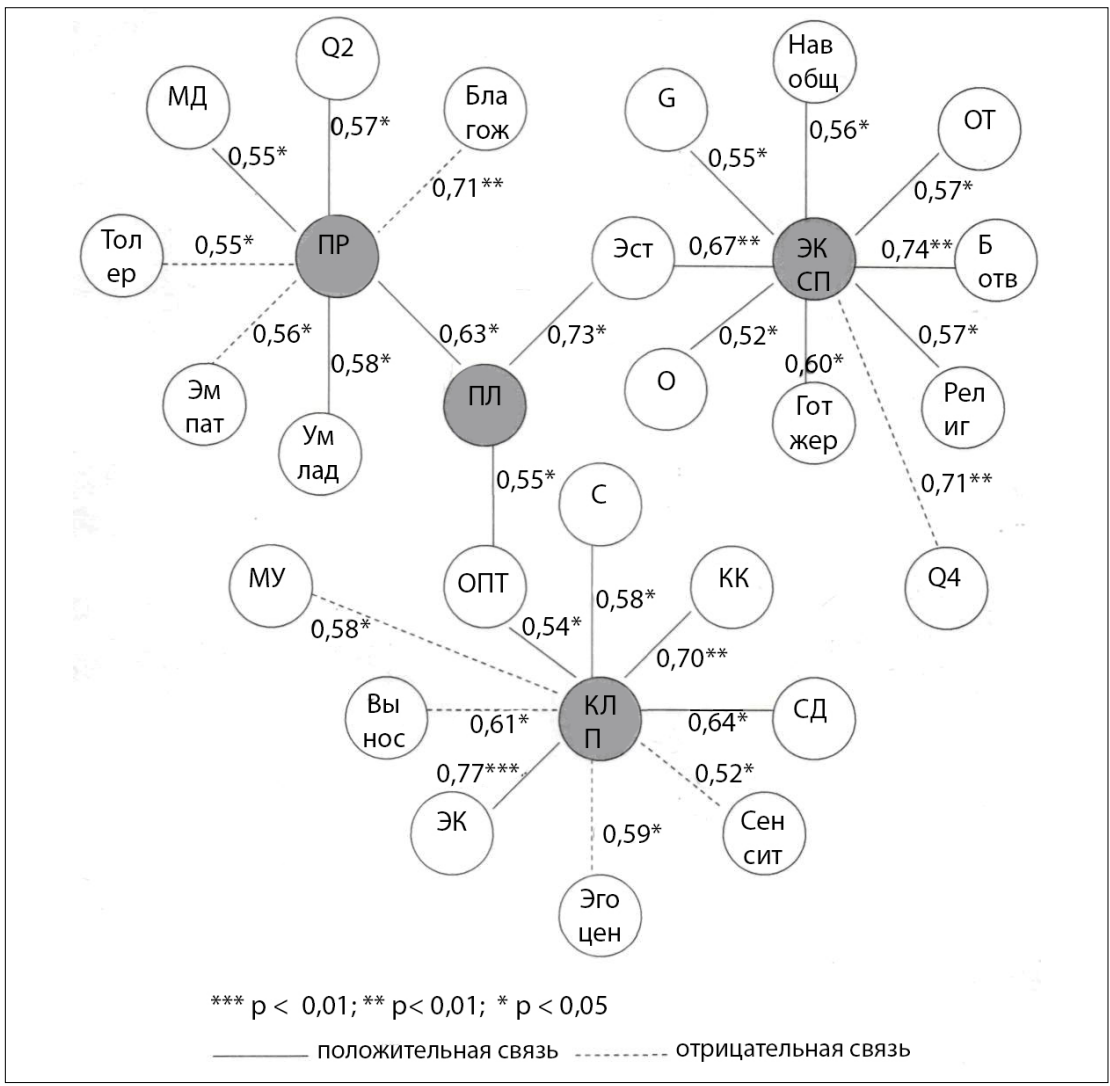

Рисунок 4. Корреляционные связи отлельных параметров понимания Аругих ^юдей в группе испытуемых с высоким уровнем эго-компетентности Аичности

Условные обозначения: КЛП - коммуникативно-личностный потенциал; ПЛ - понимание людей; ЭКСП - понимание состояния человека по его невербальному поведению; ПР - точность прогнозирования развития ситуачии межличностного взаимодействия; Q2 - нонконформизм; ОПТ - оптимизм; Благож. - благожелательность по отношению к людям; Толер. - толерантность; СД - самодостаточность; Б. отв. - боязнь отвержения; G - сила сверх-Я; Эмпат. - эмпатия; Ум. лад. - умение ладить, спорить, договариваться; C - эмоциональная стабильность; КК - коммуникативная компетентность; Эгоцен. - эгоцентризм; ЭК - эго-компетентность; Выносл. - выносливость, работоспособность; МУ - моральные установки; МД - мотивация достижения; Сенсит. - сенситивность; О - тревожность, чувство вины; Нав. общ. - навыки общения; Гот. жерт. - готовность жертвовать; Эст. - эмоциональная устойчивость; Q4 - напряженность; ОТ - стабильность человеческих отношений; Религ. - религиозность.

Figure 4. Correlations among particular components of the ability to understand others in the group of respondents with a high level of personal ego-competence 


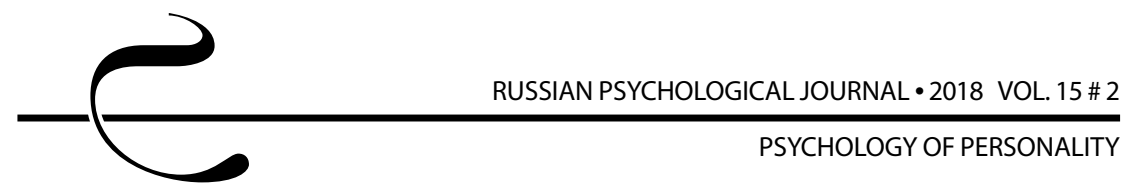

Высокая оценка собственной способности к пониманию людей напрямую связана с эмоциональной стабильностью и оптимизмом личности. По всей видимости, обладание данными свойствами дает человеку уверенность в том, что он может понять другого человека и у него это хорошо получается.

Способность к точному прогнозированию развития ситуации межличностного взаимодействия связана с высоким уровнем развития мотивации достижений, высокой самооценкой собственного умения ладить с людьми, договариваться.

Можно предположить, что в основе развития данной способности у эгокомпетентных людей лежит опыт взаимодействия в ситуации, значимой для достижения успеха в деле. Чем более они заинтересованы в нем, чем больше усилий прилагают, тем точнее будут их прогнозы развития ситуации, понимание мотивов поведения людей, с которыми они взаимодействуют.

Кроме того, успешность понимания развития ситуации у данной группы испытуемых сочетается с недоброжелательностью по отношению к другим людям, несклонностью к проявлениям сочувствия, сопереживания, независимостью, нетерпимостью к мнениям, расходящимся с их собственным, ориентацией на себя и свои решения.

Таким образом, развитию точности прогнозирования изменения ситуации способствует опыт общения с людьми, не вызывающими положительных эмоций, с которыми сложились негативные отношения. Взаимодействие в подобной ситуации требует рационального подхода, понимания мотивов поведения человека, просчитывания дальнейших действий. С другой стороны, возможно, что логический уровень познания актуализируется у эго-компетентных людей в ситуациях, связанных с некоторой жесткостью по отношению к другому человеку, проявляющейся в нетерпимости, отсутствии сочувствия, сопереживания по отношению к нему, а также вызванных необходимостью отстаивания своего мнения, что в свою очередь ведет к развитию точности прогнозирования ситуации взаимодействия.

Понимание состояния другого человека по его невербальным реакциям связано с боязнью быть отвергнутыми другими людьми, высокой нормативностью поведения, добросовестностью, ответственностью, умением контролировать свои эмоции, спокойствием, низкой мотивацией, тревожностью, ранимостью, неуверенностью в себе, чувствительностью к одобрению окружающих, религиозностью личности, готовностью жертвовать для блага Других своими личными интересами, развитыми навыками общения, высокой ценностью стабильных и прочных отношений с другими людьми.

Исходя из этого, можно предположить, что ориентированность на внешний рисунок поведения другого человека, точность распознавания состояний человека по его невербальным реакциям связаны с зависимостью личности 
от него, боязнью потерять, неуверенностью в себе, желанием следовать установленным правилам, традициям, со стремлением сохранить отношения. По всей видимости, данная способность выполняет важную функцию в регулировании межличностных отношений. С одной стороны, она сигнализирует об отношении другого человека, с другой стороны, является формой проявления собственного отношения к нему.

Обратимся к показателям противоположной группы испытуемых (рисунок 5).

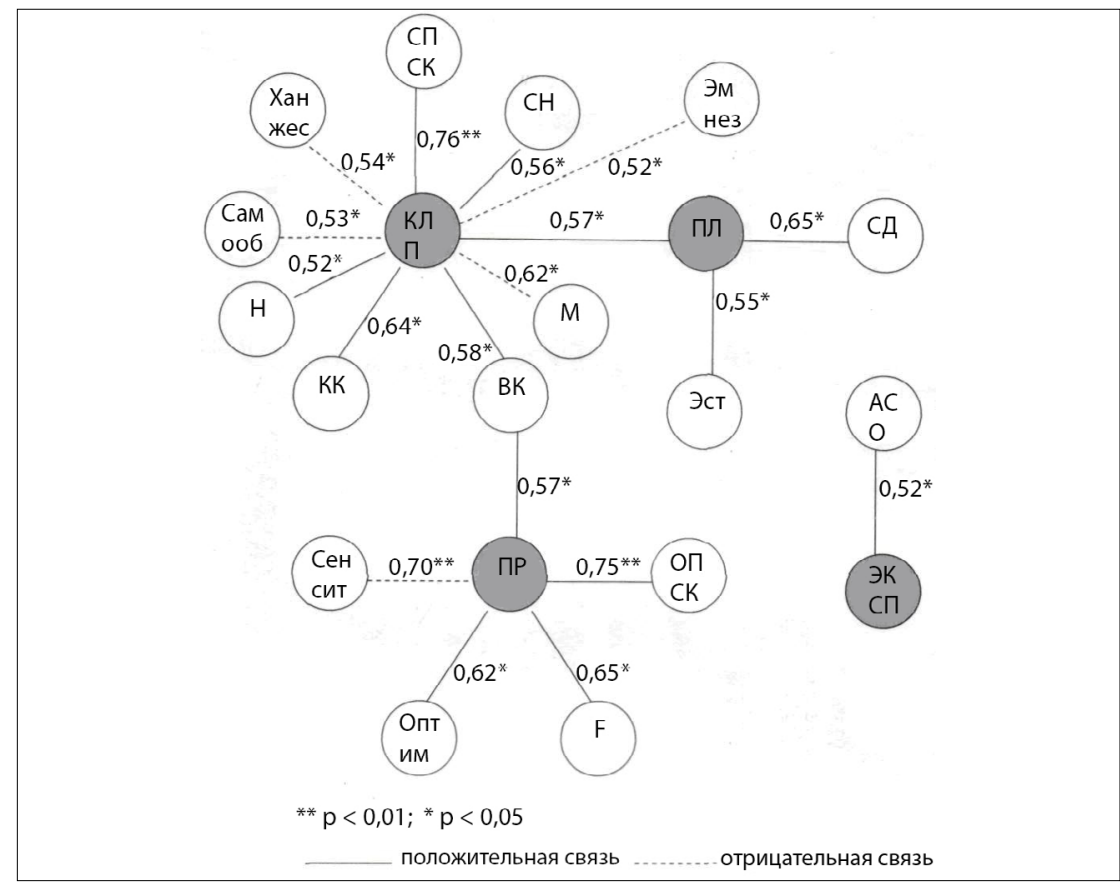

Рисунок 5. Корреляционные связи отАельных параметров понимания Аругих ^юАей в группе испытуемых с низким уровнем эго-компетентности Аичности

Условные обозначения: КЛП- коммуникативно-личностный потенциал; ПЛ- понимание людей; ЭКСП - понимание состояния человека по его невербальному поведению; ПР - точность прогнозирования развития ситуации межличностного взаимодействия; СПСК - социально-психологическая компетентность; Эм. нез. - эмоциональная незрелость; $\mathrm{CH}$ - сноровка; $\mathrm{M}$ - мечтательность; ВК - вербальная компетентность; H-смелость; Самооб. - самообладание; Ханжес. - ханжеские установки; СД - самодостаточность; ОПСК - оперативная социальная компетентность; F- беспечность, импульсивность; АСО - асоциальность поведения; Оптим. - оптимизм; КК - коммуникативная компетентность; Сенсит. - сенситивность; Эст. - эмоциональная устойчивость.

Figure 5. Correlations among particular components of the ability to understand others in the group of respondents with a low level of personal ego-competence 


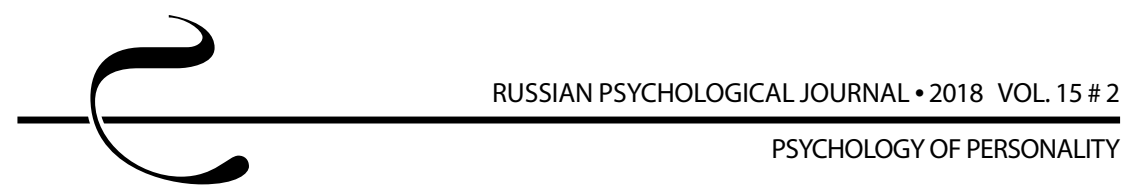

У эго-некомпетентных испытуемых высокий уровень развития коммуникативно-личностного потенциала наиболее тесно связан с социальнопсихологической компетентностью и коммуникативной компетентностью личности - и это подтверждает тот факт, что коммуникативно-личностный потенциал выступает, в первую очередь, коммуникативным ядром социального интеллекта. Помимо этого, положительные связи с эмоциональной зрелостью, смелостью, активностью личности, не склонностью к ханжеству и догматизму, практичностью говорят о том, что высокий уровень его развития сочетается с активной деятельностной позицией человека, не останавливающегося перед условностями, сложностями, способного контролировать свои эмоции, готового к риску для достижения поставленных целей.

Высокая оценка собственной способности к пониманию людей связана с самодостаточностью личности, эмоциональной стабильностью. Можно предположить, что эти показатели, и в первую очередь ощущение самодостаточности, дают человеку уверенность в том, что он понимает людей. С другой стороны, опыт гармоничных отношений, наполненных пониманием окружающих людей, спокойствием, может способствовать формированию чувства самодостаточности, уверенности человека в себе.

Способность прогнозировать развитие ситуации межличностного взаимодействия связана с высокой общей социальной ориентированностью и осведомленностью, позволяющей быстро решать возникающие в социальном взаимодействии задачи, вербальной компетентностью, а также низким уровнем сенситивности личности, экспрессивностью личности, жизнерадостностью, динамичностью общения, эмоциональной значимостью контактов.

Таким образом, точность прогнозирования развития ситуации предполагает наличие опыта социального взаимодействия, владение специальными социально-психологическими знаниями и вербальными навыками, достаточную жесткость, нечувствительность личности. Кроме того, умению прогнозировать способствуют динамичные, эмоционально значимые контакты.

В ходе корреляционного анализа у испытуемых данной группы была выявлена положительная связь между показателями понимания состояния другого человека по его невербальным реакциям и асоциальности поведения, проявляющегося в необязательности, способности к обману и т. д. Можно предположить, что подобного рода поведенческие реакции предполагают ориентированность на внешний рисунок поведения человека.

\section{Обсуждение результатов}

Результаты, полученные в исследовании, дают широкий спектр информации по вопросу эго-компетентности личности и ее связи со способностью 
к пониманию других людей в юношеском возрасте. На основании полученных данных можно сделать следующие выводы:

1. Большинство юношей и девушек отличает средний уровень эго-компетентности личности (56\%). Гораздо меньше тех, кто ориентирован на самопознание, хорошо осведомлен о своих индивидуальных особенностях (14\%). Значительная часть испытывает трудности в познании себя (30\%).

2. Компетентность в собственном Я в юношеском возрасте сочетается с уверенностью в себе, эмоциональной устойчивостью личности, удовлетворенностью собой и своим общением с близкими людьми, отсутствием предубеждений, социально-психологической компетентностью, доброжелательностью по отношению к людям, толерантностью, высокой общей социальной ориентированностью, коммуникативной компетентностью, осведомленностью и предприимчивостью.

3. Эго-компетентность личности в юношеском возрасте связана с высоким уровнем коммуникативно-личностного потенциала и самооценки понимания других людей. Точность прогнозирования развития ситуации межличностного взаимодействия и понимание невербального поведения могут сочетаться с разным уровнем развития эго-компетентности личности.

4. Эго-компетентные люди, в отличие от эго-некомпетентных, на уровне статистической значимости имеют более высокий (выше среднего) уровень развития коммуникативно-личностного потенциала. На уровне тенденции следует отметить их большую успешность в межличностном понимании. Вместе с тем показатели развития отдельных составляющих способности к пониманию других людей у них не превышают средних величин. В меньшей степени развита способность к прогнозированию развития ситуации межличностного взаимодействия.

5. Установлены как общие, так и специфические взаимосвязи параметров понимания с отдельными свойствами личности у групп людей с разным уровнем эго-компетентности:

а) коммуникативно-личностный потенциал в обеих группах связан с показателями развития коммуникативных качеств, эмоциональной зрелостью личности, уверенностью в себе, ориентированностью на свои мнения и убеждения. Отличия состоят в том, что у эго-компетентных людей коммуникативно-личностный потенциал сочетается с эго-компетентностью личности, ориентированностью не только на себя, но и на других людей. У эго-некомпетентных людей в большей степени представлены связи коммуникативноличностного потенциала с социально-психологической компетентностью, предприимчивостью, готовностью к совершению рискованных поступков;

б) высокая оценка своей способности к пониманию людей в обеих группах связана с эмоциональной стабильностью личности. Различия же 


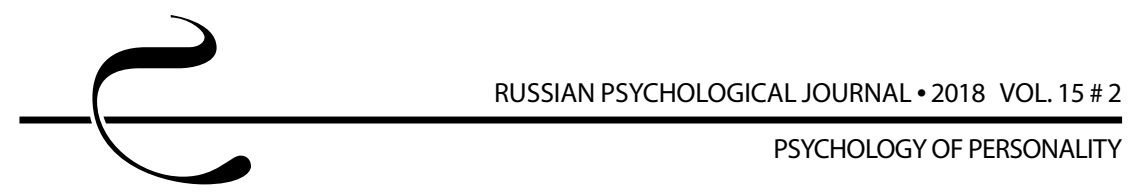

состоят в том, что у эго-некомпетентных людей самооценка понимания может служить индикатором самодостаточности личности, у эго-компетентных людей - лишь говорить об их оптимистическом настрое, в том числе в отношении понимания людей;

в) способность к прогнозированию развития ситуации межличностного взаимодействия в обеих группах связана с опытом социального взаимодействия в эмоционально насыщенных ситуациях, предполагает достаточную жесткость личности, рациональность. Особенности состоят в том, что у эго-компетентных людей данная способность актуализируется в значимой для них ситуации, при общении с людьми, не вызывающими положительных эмоций, с которыми сложились непростые отношения. У эго-некомпетентных людей точность прогнозирования развития ситуации предполагает высокую степень социальной ориентированности, осведомленности, вербальную компетентность, связана с динамичностью общения, экспрессивностью и нечувствительностью;

г) способность к пониманию невербального поведения связана с ориентированностью на внешний рисунок поведения другого человека. Помимо этого, у эго-компетентных людей данная способность, с одной стороны, сигнализирует об отношении другого человека, с другой стороны, является формой проявления собственного отношения к нему. У эго-некомпетентных людей понимание состояния человека по его невербальным реакциям сочетается с поведением, отличающимся необязательностью, способностью к обману и т. д.

Таким образом, полученные данные расширяют представление о юношах и девушках как субъектах межличностного познания, об особенностях взаимосвязи эго-компетентности личности со способностью к пониманию других людей в юношеском возрасте.

\section{Литература}

1. Познание человека человеком (возрастной, гендерный, этнический и профессиональный аспекты) / под ред. А. А. Бодалева, Н. В. Васиной. СПб.: Речь, 2005. 322 с.

2. Андреева Г.М. Психология социального познания:учебное пособие. М.: Аспект Пресс, 2000. 288 с.

3. Юшачкова Т. Б. Личностные детерминанты способности к пониманию других людей: дисс. ... канд. психол. наук. СПб., 2006. 194 с.

4. Boh/ V. We read minds to shape relationships // Philosophical Psychology. 2015. Vol. 28, Issue 5. P. 674-694. DOI: $10.1080 / 09515089.2014 .893607$

5. Cabinio M., Rossetto F., Blasi V., et al. Mind-Reading Ability and Structural Connectivity Changes in Aging // Frontiers in Psychology. 2015. Vol. 6. DOI: 10.3389/fpsyg.2015.01808 
6. Habota T., McLennan S. N., Cameron J., et al. An Investigation of Emotion Recognition and Theory of Mind in People with Chronic Heart Failure // PLoS one. 2015. Vol. 10 (11). e0141607. DOI: $10.1371 /$ journal.pone.0141607

7. Lecce S., Ceccato I., Bianco F., et al. Theory of Mind and social relationships in older adults: the role of social motivation // Aging \& Mental Health. 2017. Vol. 21, Issue 3. P. 253-258. DOI: 10.1080/13607863.2015.1114586

8. Pezzuti L., Longobardi E., Rossetti S., et al. The Relation between the Theory of Mind and Socio-Emotional Functioning in a Sample of Older Adults // Journal of Neurology and Psychology. 2015. Vol. 3, Issue 2. P. 1-7. DOI: 10.13188/2332-3469.1000021

9. Plana I., Lavoie M.-A., Battaglia M., Achim A. M. A meta-analysis and scoping review of social cognition performance in social phobia, posttraumatic stress disorder and other anxiety disorders // Journal of Anxiety Disorders. 2014. Vol. 28, Issue 2. P. 169-177. DOI: 10.1016/j.janxdis.2013.09.005

10. Бубер М. Два образа веры. М.: Республика, 1995. 464 с.

11. Сартр Ж.-П. Бытие и ничто: опыт феноменологической онтологии. М.: Республика, 2000. 639 с.

12. ЯсперсК. Всемирная история философии. Введение. СПб.: Наука, 2000. 272 с.

13. Маркс К., Энгельс Ф. Сочинения. Т. 23. Изд. 2-е. М.: Государственное изд-во политической литературы, 1960. 907 с.

14. Allport G. W. Personality: A Psychological Interpretation. N. Y.: Henry Holt \& Co, $1937.588 \mathrm{p}$.

15. Борисова А. А. Психологическая проницательность. Ярославль: Изд-во ЯГПУ, 1999. $447 \mathrm{c.}$

16. Лабунская В. А. Экспрессия человека: общение и межличностное познание. Ростов н/Д.: Феникс, 1999. 608 с.

17. Кондратьева С. В. Межличностное понимание и его роль в общении (на материале средней общеобразовательной школы): дисс. д. психол. наук. Дрогобыч, 1977. 434 с.

18. Ананьев Б. Г. О проблемах современного человекознания. СПб.: Питер, 2001. 272 c.

19. Рубинштейн С. Л. Основы общей психологии. СПб.: Питер, 2009. 720 с.

20. Бодалев А. А. Восприятие и понимание человека человеком. М.: Изд-во МГУ, 1982. $200 \mathrm{c}$.

21. Андреева Г. М. Социальная психология: учебник для высших учебных заведений. М.: Аспект Пресс, 2006. 363 с.

22. Петровская Л. А. Общение - компетентность - тренинг: Избранные труды. М.: Смысл, 2007. 387 с.

23. Бодалев А. А. Психология общения. М.: Изд-во Института практической психологии; Воронеж: НПО «МОДЭК», 1996. 256 с. 
24. Знаков В. В. Понимание в мышлении, общении, человеческом бытии. М.: Изд-во Института психологии РАН, 2007. 479 с.

25. Кроник А. А., Кроник Е. А. Психология человеческих отношений. Дубна: Издательский центр «Феникс», Изд-во «Когито-Центр»+, 1998. 224 с.

26. Куницына В. Н. Трудности межличностного общения: дисс. ... д. психол. наук. СПб., 1991. 358 с.

27. Психология общения. Энциклопедический словарь / под общ. ред. А. А. Бодалева. М.: Когито-Центр, 2011.600 с.

28. Матьяш О. И., Погольша В. М., Казаринова Н. В., Биби С., Зарицкая Ж. В. Межличностная коммуникация: теория и жизнь / под науч. ред. О. И. Матьяш. СПб.: Речь, 2011. 560 с.

29. Реан А. А. Психология познания педагогом личности учащихся. М.: Высшая школа, 1990.80 с.

30. Стрелкова И. Э. Влияние личностных свойств на адекватность оценивания людьми друг друга // Проблемы оценивания в психологии / отв. ред. Л. П. Доблаев. Саратов: Изд-во Саратовского ун-та, 1983. С. 14-19.

31. Южанинова А. Л. Связь социального интеллекта с некоторыми индивидуально-личностными особенностями // Прикладные проблемы психологии личности: межвуз. науч. сб. / под ред. Л. П. Доблаева. Саратов: Изд-во Саратов. ун-та, 1985. С. 65-73.

32. Манеров В. Х. Экспериментально-теоретические основы социальной идентификации и интерпретации говорящего: дисс. ... д. психол. наук. СПб., 1993. 457 с.

33. Морозов В. П. Психологический портрет человека по невербальным особенностям его речи // Психологический журнал. 2001. Т. 22, № 6. C. 48-63.

\section{References}

1. Bodalev A. A., Vasina N. V. (eds.) Poznanie cheloveka chelovekom (vozrastnoi, gendernyi, etnicheskii i professional'nyi aspekty) [Cognition of a man by another man: Age, gender, ethnic, and professional aspects]. St. Petersburg, Rech' Publ., 2005. 322 p.

2. Andreeva G. M. Psikhologiya sotsial'nogo poznaniya [Psychology of social cognition]. Moscow, Aspekt Press Publ., 2000. 288 p.

3. Yushachkova T. B. Lichnostnye determinanty sposobnosti k ponimaniyu drugikh lyudei [Personal determinants of the ability to understand others]. Diss. Cand. Sci. (Psych.). St. Petersburg, 2006. 194 p.

4. Bohl V. We read minds to shape relationships. Philosophical Psychology, 2015, V. 28, Issue 5, pp. 674-694. DOI: 10.1080/09515089.2014.893607 
5. Cabinio M., Rossetto F., Blasi V., et al. Mind-reading ability and structural connectivity changes in aging. Frontiers in Psychology, 2015, V. 6. DOI: 10.3389/fpsyg.2015.01808

6. Habota T., McLennan S. N., Cameron J., et al. An investigation of emotion recognition and theory of mind in people with chronic heart failure. PLoS one, 2015, V. 10 (11), e0141607. DOI: 10.1371/journal.pone.0141607

7. Lecce S., Ceccato I., Bianco F., et al. Theory of mind and social relationships in older adults: The role of social motivation. Aging \& Mental Health, 2017, Vol. 21, Issue 3, pp. 253-258. DOI: 10.1080/13607863.2015.1114586

8. Pezzuti L., Longobardi E., Rossetti S., et al.The relation between the theory of mind and socio-emotional functioning in a sample of older adults. Journal of Neurology and Psychology, 2015, V. 3, Issue 2, pp. 1-7. DOI: 10.13188/2332-3469.1000021

9. Plana I., Lavoie M.-A., Battaglia M., Achim A. M. A meta-analysis and scoping review of social cognition performance in social phobia, posttraumatic stress disorder and other anxiety disorders. Journal of Anxiety Disorders, 2014, V. 28, Issue 2, pp. 169-177. DOI: 10.1016/j.janxdis.2013.09.005

10. Buber M. Two Types of Faith. N. Y., Harper and Brothers, 1961 (Russ. ed.: Buber M. Dva obraza very. Moscow, Respublika Publ., 1995. 464 p.).

11. Sartre J.-P. Being and nothingness: An essay in phenomenological ontology. London and New York, Routledge, 2003 (Russ. ed.: Sartr Zh.-P. Bytie i nichto: opyt fenomenologicheskoi ontologii. Moscow, Respublika Publ., 2000.639 p.).

12. Jaspers K. The world history of philosophy: Introduction (Russ. ed.: Yaspers K. Vsemirnaya istoriya filosofii. St. Petersburg, Nauka Publ., 2000. 272 p.).

13. Marx K., Engels F. Works: V. 23 (Russ. ed.: Marks K., Engel's F. Sochineniya. T. 23. Moscow, Gosudarstvennoe izd-vo politicheskoi literatury Publ., 1960. 907 p.).

14. Allport G. W. Personality: A psychological interpretation. N. Y., Henry Holt \& Co, 1937. $588 \mathrm{p}$.

15. Borisova A. A. Psikhologicheskaya pronitsatel'nost' [Psychological insight]. Yaroslavl, Yaroslavl State Pedagogical University Publ., 1999. 447 p.

16. Labunskaya V. A. Ekspressiya cheloveka: obshchenie i mezhlichnostnoe poznanie [Human expression: Communication and interpersonal cognition]. Rostov-on-Don, Feniks Publ., 1999. 608 p.

17. Kondrat'eva S. V. Mezhlichnostnoe ponimanie i ego rol'v obshchenii (na materiale srednei obshcheobrazovatel'noi shkoly) [Interpersonal understanding and its role in communication: A case study of secondary schools]. Diss. Dr. Sci. (Psych.). Drogobych, 1977. 434 p.

18. Anan'ev B. G. O problemakh sovremennogo chelovekoznaniya [On the problems of modern human study]. St. Petersburg, Piter Publ., 2001. 272 p.

19. Rubinshtein S. L. Osnovy obshchei psikhologii [Fundamentals of general psychology]. St. Petersburg, Piter Publ., 2009. 720 p. 
20. Bodalev A. A. Vospriyatie i ponimanie cheloveka chelovekom [Perception and cognition of a man by another man]. Moscow, Moscow State University Publ., 1982. $200 \mathrm{p}$.

21. Andreeva G. M. Sotsial'naya psikhologiya [Social psychology]. Moscow, Aspekt Press Publ., 2006. 363 p.

22. Petrovskaya L. A. Obshchenie - kompetentnost' - trening [Communication, competence, and training]. Moscow, Smysl Publ., 2007. 387 p.

23. Bodalev A. A. Psikhologiya obshcheniya [Psychology of communication]. Moscow, Institute of Practical Psychology Publ., 1996. 256 p.

24.Znakov V. V. Ponimanie v myshlenii, obshchenii, chelovecheskom bytii [Understanding in thinking, communication, and human existence]. Moscow, Institute of Psychology, RAS Publ., 2007. 479 p.

25. Kronik A. A., Kronik E. A. Psikhologiya chelovecheskikh otnoshenii [Psychology of human relations]. Dubna, Feniks Publ., 1998. 224 p.

26. Kunitsyna V. N. Trudnosti mezhlichnostnogo obshcheniya [Difficulties in interpersonal communication]. Diss. Dr. Sci. (Psych.). St. Petersburg, 1991. 358 p.

27. Bodalev A. A. Psikhologiya obshcheniya. Entsiklopedicheskii slovar' [Psychology of communication: Encyclopedic dictionary]. Moscow, Kogito-Tsentr Publ., $2011.600 \mathrm{p}$.

28. Mat'yash O. I., Pogol'sha V. M., Kazarinova N. V., Bibi S., Zaritskaya Zh. V. Mezhlichnostnaya kommunikatsiya: teoriya i zhizn' [Interpersonal communication: Theory and life]. St. Petersburg, Rech' Publ., 2011.560 p.

29. Rean A. A. Psikhologiya poznaniya pedagogom lichnosti uchashchikhsya [Psychology of the teacher's cognition of students' personalities]. Moscow, Vysshaya shkola, 1990.80 p.

30. Strelkova I. E. Effect of personality traits on the adequacy of individuals' evaluating each other. In: L. P. Doblaev (ed.) Problemy otsenivaniya v psikhologii [Evaluating problems in psychology]. Saratov, Saratov University Publ., 1983, pp. 14-19.

31. Yuzhaninova A. L. Interrelation between social intelligence and particular individual personality traits. In: L. P. Doblaeva (ed.) Prikladnye problemy psikhologii lichnosti [Applied problems of personality psychology]. Saratov, Saratov University Publ., 1985, pp. 65-73.

32. Manerov V. Kh. Eksperimental'no-teoreticheskie osnovy sotsial'noi identifikatsii i interpretatsii govoryashchego [Experimental and theoretical foundations for a speaker's social identification and interpretation]. Diss. Dr. Sci. (Psych.). St. Petersburg, 1993. $457 \mathrm{p}$.

33. Morozov V. P. Psychological portrait of a man constructed by nonverbal peculiarities of the speech. Psikhologicheskii zhurnal, 2001, V. 22, no. 6, pp. 48-63 (in Russian). 